\title{
Film with anthocyanins as an indicator of chilled pork deterioration
}

\author{
Filme com antocianinas como indicador da deterioração de carne suína refrigerada
}

\author{
Luana Baptista GOLASZ1, Janice da SILVA , Suse Botelho da SILVA ${ }^{1 *}$
}

\begin{abstract}
An indicator can be defined as a substance which indicates the presence or absence of another substance or the degree of a certain reaction through characteristic changes, especially color. Therefore, the aim of this work is to evaluate the performance of a bio-based film with anthocyanin as an indicator of chilled pork deterioration. A film made of cassava starch, glycerol, and grape anthocyanins was prepared using the casting technique. Pork loin samples were put in Petri dishes containing an anthocyanin film on the bottom and stored at $4{ }^{\circ} \mathrm{C}$. Psychrotrophic microorganism count and the $\mathrm{pH}$ of the pork loin samples were analyzed for a 14 day- period. At the same time, the films were subjected to colorimetric analysis using D65 illuminant and the CIELAB system. Chroma and hue angle data for these films were evaluated by Anova and Dunnett's test. An increase in the microbial population and in the $\mathrm{pH}$ was observed over the storage period as result of pork deterioration. Color changes were also identified in the film. However, only at the beginning of the storage period was it possible to establish a correlation between film color and pork deterioration. The shelf life end-point could not be clearly detected by the film.

Keywords: indicator; anthocyanins; chilled pork; color; deterioration.
\end{abstract}

\section{Resumo}

Um indicador pode ser definido como uma substância que indica a presença ou ausência de outra substância ou o grau de avanço de uma reação. Neste contexto, o objetivo deste trabalho é avaliar o desempenho de um filme com antocianinas como indicador da deterioração em carne suína refrigerada. Deste modo, um filme de fécula de mandioca, glicerol e antocianinas foi elaborado segundo a técnica de casting. Porções de lombo suíno foram colocadas em placas de Petri com um filme de antocianinas no fundo e foram armazenadas a $4{ }^{\circ} \mathrm{C}$. Durante 14 dias, foram avaliados a contagem de microrganismos psicrotróficos e o $\mathrm{pH}$ da carne. Paralelamente, os filmes foram submetidos à análise colorimétrica usando o iluminante D65 e o sistema CIELAB. Os dados de cromaticidade e tonalidade foram avaliados pela análise de variância e teste de Dunnett. Durante o armazenamento, observou-se um aumento na população microbiana e elevação do $\mathrm{pH}$, como resultado da deterioração da carne. Ao mesmo tempo, foram detectadas mudanças de cor no filme. No entanto, somente no início do período de estocagem, foi possível estabelecer uma correlação entre a cor do filme e deterioração da carne de porco. O ponto final da vida de prateleira não foi claramente identificado.

Palavras-chave: indicador; antocianinas; carne suína refrigerada; coloração; deterioração.

\section{Introduction}

Conventional packaging has four basic functions: contain, protect, inform, and provide convenience during storage and distribution steps with minimal interaction between packaging and content (ROBERTSON, 1993). On the other hand, active and intelligent packaging interacts deliberately with the product in order to improve food quality and safety. Thus, active and intelligent packaging extend the protection and information functions of traditional packaging (DAINELLI et al., 2008; RESTUCCIA et al., 2010; YAM; TAKHISTOV; MILTZ, 2005).

Intelligent packaging is a system capable of monitoring food conditions in real time, enhancing possibilities to monitor product quality, trace critical points, and give more detailed information throughout the supply chain (HAN; HO; RODRIGUES, 2005; KRUIJUF et al., 2002; KUSWANDI et al., 2011). The information is communicated through direct visual changes. The intelligent packaging system can be used as a sachet, attached as labels or tags, incorporated into, or printed onto packaging material (HAN; HO; RODRIGUES,
2005; RESTUCCIA et al., 2010). Examples of intelligent packaging are time-temperature indicators (TTI's), gas sensing devices, freshness indicators, and microbial growth and toxin indicators (AHVENAINEN, 2003; DAINTY, 1996; HORAN, 1998; PAVELKOVÁ, 2012; PULIGUNDLA; JUNG; KO, 2012; RESTUCCIA et al., 2010; SOARES et al., 2009). According to Kerry, O'Grady and Hogan (2006), an indicator can be defined as a substance which indicates the presence or absence of another substance or the degree of reaction between two or more substances through changes in the indicator characteristics, especially color changes. The detection of chemical changes associated with microbial growth by indicators can offer an alternative to sensory and microbiological analyses which are often costly and time-consuming (DAINTY, 1996).

The number of published studies on food spoilage indicators is still limited. Some trials, however, report that freshness indicators are designed to respond to chemicals released by food as a result of spoilage; usually an oxidative process is caused

${ }^{1}$ Polytechnic School, University of Vale do Rio dos Sinos - UNISINOS, Av. Unisinos, 950, CP 275, CEP 93022-000, São Leopoldo, RS, Brazil, e-mail: susebs@unisinos.br ${ }^{*}$ Corresponding author 
by microorganisms, which break down food carbohydrates, proteins, and fats to a wide variety of low-molecular-weight molecules (RANDELL et al., 1995; MATTILA; TAWAST; AHVENAINEN, 1990).

It is observed that existing studies use chemical indicators in petrochemical-based polymeric matrices. A myoglobin-based indicator has been developed for modified-atmosphere packed poultry to indicate spoilage by detecting presence of hydrogen sulfide $\left(\mathrm{H}_{2} \mathrm{~S}\right)$ (SMOLANDER et al., 2002). Pacquit et al. (2006, 2007) also developed a colorimetric dye-based sensor that detects the presence of total volatile basic nitrogen (TVB-N) for monitoring of fish spoilage. Nopwinyuwong et al. (2010) developed a colorimetric mixed $\mathrm{pH}$ dye-based indicator (bromothymol blue and methyl red) with potential for the development of intelligent packaging as a "chemical barcode" for real-time monitoring of intermediate-moisture dessert spoilage.

Both petrochemical-based and bio-based materials can be used in the prodution of intelligent packaging systems although the latter is generally more compatible for food-contact applications since it has eco-friendly attributes and higher consumer acceptance (BOTREL et al., 2007; RESTUCCIA et al., 2010; YAM; TAKHISTOV; MILTZ, 2005). Renewable resources used as matrix of intelligent packaging can include polymers directly extracted from biomass such as natural proteins, lipids, and polysaccharides; polymeric materials synthesized by polymerization procedure using bio-based monomers such as poly(lactic acid); or polymeric materials produced by microorganisms such as polyhydroxyalkanoates (SIRACUSA et al., 2010).

Some natural pigments from vegetable sources, anthocyanins for example, have great potential as indicators in intelligent packaging systems. These flavonoids are widely spread in nature comprising the largest group of water-soluble plant pigments, and they have been isolated mainly from flowers and fruits (ALIBERT, 2009; BORDIGNON JUNIOR et al., 2009; FAVARO, 2008; GOUVÊA et al., 2012; LIMA, 2011; STRACK; WRAY, 1994). Color expression of anthocyanins is strongly influenced by its structure, $\mathrm{pH}$, co-pigmentation, temperature, UV radiation, and presence of oxygen providing different colors that range from salmon-pink through red and violet to nearly black (FRANCIS, 1989; GONNET, 1998; MAZZA; BROUILLARD, 1990; TORSKANGERPOLL; ANDERSEN, 2005). This color instability of anthocyanins makes these pigments especially useful to monitor food quality and therefore can be used as an indicator of food spoilage in intelligent packaging systems.

Maciel, Yoshida and Franco (2012) developed a biodegradable packaging material based on the anthocyanin incorporation into a chitosan matrix to be applied as a temperature indicator. This system was formulated as a coating on a card paper surface. Veiga-Santos, Ditchfield and Tadini (2011) developed biodegradable film with grape and spinach extracts (anthocyanin and chlorophyll) incorporated into a cassava starch matrix and evaluated the color change at different $\mathrm{pH}$ values. Both studies presented a wide characterization of these materials including mechanical properties, water vapor barrier, and microstructure although not applied to food systems. The aim of this study is to evaluate the performance of a bio-based film made of cassava starch, glycerol, and anthocyanin as an indicator of the deterioration of chilled pork. For 14 days, pork deterioration was assessed by microbiological and $\mathrm{pH}$ analysis; the film was subjected to colorimetric analysis.

\section{Materials and methods}

\subsection{Materials}

Cassava starch (Yoki Alimentos, São Bernardo do Campo, Brazil), anthocyanin extracted from grape skin, Vitis vinifera L. (AC 12r WSP, CHR Hansen Brasil, Valinhos, Brazil), and glycerol (Vetec Química Fina, Duque de Caxias, Brazil) were used as raw materials to prepare the films used in this study.

Pork loin (Longissimus dorsi) was purchased from a local market 1-2 days postmortem and transported under refrigeration $\left(4{ }^{\circ} \mathrm{C}\right)$ to our laboratory. No breed, age, sex or premortem handlings were recorded.

\subsection{Film preparation}

Films were prepared from a filmogenic suspension of cassava starch $(3 \% \mathrm{~m} / \mathrm{m})$, glycerol $(3 \% \mathrm{~m} / \mathrm{m})$, and anthocyanins $(0.5 \% \mathrm{~m} / \mathrm{m})$ using the casting technique. The film formula was developed by Silva et al. (2011), who defined the ideal amount of plasticizer.

Film-forming suspension was obtained under slow and constant stirring up to $70^{\circ} \mathrm{C}$ for starch gelatinization. Afterwards, the suspension was kept at $25^{\circ} \mathrm{C}$ in a rotary evaporator under vacuum $(-80 \mathrm{kPa})$ (Marconi, MA 120, Piracicaba, Brazil) for 5 minutes in order to dissipate bubbles formed by stirring. The film was cast into Petri dishes $\left(65 \mathrm{~cm}^{2}\right)$ using $35 \mathrm{~g}$ of suspension per dish. The petri dishes were dried under renewable circulated air in a temperature-controlled chamber (Fanem, 320/1-SE, Guarulhos, Brazil) at $40{ }^{\circ} \mathrm{C}$ for 24 hours, followed by storage at controlled conditions $\left(22^{\circ} \mathrm{C} \pm 2{ }^{\circ} \mathrm{C}\right.$ and $75 \%$ of relative humidity) for 48 hours.

\subsection{Sample preparation}

In order to reduce surface microbial contamination of pork loin, approximately $5 \mathrm{~mm}$ of the meat from surface were cut using a sterile knife under aseptic conditions in a laminar flow cabinet. Loin was sectioned into $25 \mathrm{~g}$ fine slices and into blocks of about with $1.5 \mathrm{~cm} \times 1.5 \mathrm{~cm} \times 3.0 \mathrm{~cm}$. One slice and one block were placed in Petri dishes containing an anthocyanin film on the bottom. Each Petri dish with loin portions represents one sample.

\subsection{Experimental design}

Loin portions in covered Petri dishes were stored in a dark cabinet at $4{ }^{\circ} \mathrm{C}$ for 14 days. Three samples were randomly taken at day zero, 1, 3, 5, 7, 10, and 14 for analysis. The pork loin slices were used for psychrotrophic aerobic count, the block portions were used for $\mathrm{pH}$ determination, and the films in the bottom of Petri dishes were used for colorimetric analysis. Two additional 
time points were considered for $\mathrm{pH}$ analysis only, at the $8^{\text {th }}$ and $11^{\text {st }}$ day, which were also performed in triplets.

\subsection{Psychrotrophic aerobic count}

Each slice of pork loin was aseptically chopped with a sterile knife in a laminar flow cabinet and transferred to a flask with $0,1 \%(\mathrm{~m} / \mathrm{v})$ peptone water (Oxoid, São Paulo, Brazil), used as diluent. After successive decimal dilutions, psychrotrophic aerobic microorganisms were quantified by Spread Plate technique on Plate Count Agar (Oxoid, São Paulo, Brazil). The plates were incubated at $7^{\circ} \mathrm{C}$ for 10 days (AMERICAN..., 2001).

\section{$2.6 p H$}

The $\mathrm{pH}$ analysis was performed using a $\mathrm{pHmeter}$ (Digimed, DM-21, Santo Amaro, Brazil) with a penetration electrode (Digimed, DM-CF1, Santo Amaro, Brazil), which was inserted in the center of each block of pork loin.

\subsection{Colorimetric analysis}

To evaluate the color of the anthocyanin film, meat portions were removed from the Petri dishes before analysis. The color of the film in the bottom of each Petri dish was measured using a colorimeter (Konica Minolta, Chroma Meter CR 410, Tokyo, Japan). The measurements were performed using the CIELAB system (Commission Internationale de l'Eclairage 1976), D65 illuminant, and $10^{\circ} \mathrm{CIE}$ standard observer.

The values of the rectangular coordinates $\left(L^{*}, a^{*}, b^{*}\right)$ were used to calculate the perceptual correlates hue angle, $h_{a b}$ (tonality); chroma, $C^{\star}$ (intensity); and color difference, $\Delta \mathrm{E}^{\star}$ using Equations 1, 2 and 3, respectively (SCHANDA, 2007).

$h_{a b}=\arctan \left(\frac{b^{*}}{a^{*}}\right)$

$C *=\left(a^{*^{2}}+b^{* 2}\right)^{\frac{1}{2}}$

$\Delta E^{*}=\left(\Delta L^{*^{2}}+\Delta a^{*^{2}}+\Delta b^{*^{2}}\right)^{\frac{1}{2}}$

\subsection{Statistical analysis}

Data from the colorimetric analysis of the anthocyanin films were subjected to analysis of variance (One-way Anova), followed by Dunnett's test $(\mathrm{P}<0.05)$. Anthocyanin films in contact with pork loin at zero time of storage were used as the control group in Dunnett's test. All statistical analyses were carried out using the Statistica software (Statsoft, Tulsa, United States).

\section{Results and discussion}

\subsection{Psychrotrophic aerobic count}

At the time of slaughter, the muscle of the animal can be considered sterile because it is protected by the skin, which acts as an almost perfect protective layer, and by the intestinal tract which serves as an effective barrier against the immense mass of micro-organisms it contains (JAY, 2000). In addition to the physiological status of the animal at slaughter, the microbiological quality of meat depends on the spread of contamination during slaughter and processing, temperature, and other storage and distribution conditions (NYCHAS et al., 2008).

Figure 1 shows the increase in aerobic count during storage; it is possible to identify typical lag and log phases of microbial growth and a tendency to stationary phase development after 10 hours. During the meat storage, the microorganisms count increased by approximately 5 logarithmic cycles, and the increase was about $0.7 \log$ cycles/day only in the log phase (between $3^{\text {rd }}$ and $10^{\text {th }}$ day). This result was expected since psychrotrophic microorganisms dominate the microbiota of protein food stored under refrigeration, and they are the main microorganisms responsible for the deterioration of chilled meat, especially Pseudomonas spp (NYCHAS et al., 2008; JAY, 2000).

The spoilage of chilled meat is mostly a surface phenomenon resulting in the formation of slime, odors, and possibly gas production (AMERICAN..., 2001; JAY, 2000). In practice, these characteristics become evident when the Pseudomonas have exhausted the glucose and lactate present in meat and begin to metabolize nitrogenous compounds such as amino acids (NYCHAS et al. 2008; DAINTY, 1996). Therefore, sensory changes are noticeable only when the microorganisms count surpasses the values of $10^{7}$ or $10^{8} \mathrm{cfu} / \mathrm{g}$, they are considered typical levels of end of shelf-life for chilled meat (REALINI et al., 2011; NYCHAS et al., 2008; INTERNATIONAL..., 1980). Substances such as mono-, di-and trimetilaminas, ethyl and propyl compounds, ammonia, $\mathrm{H}_{2} \mathrm{~S}$, alcohols, and short chain fatty acids are found in spoiled meat and are responsible

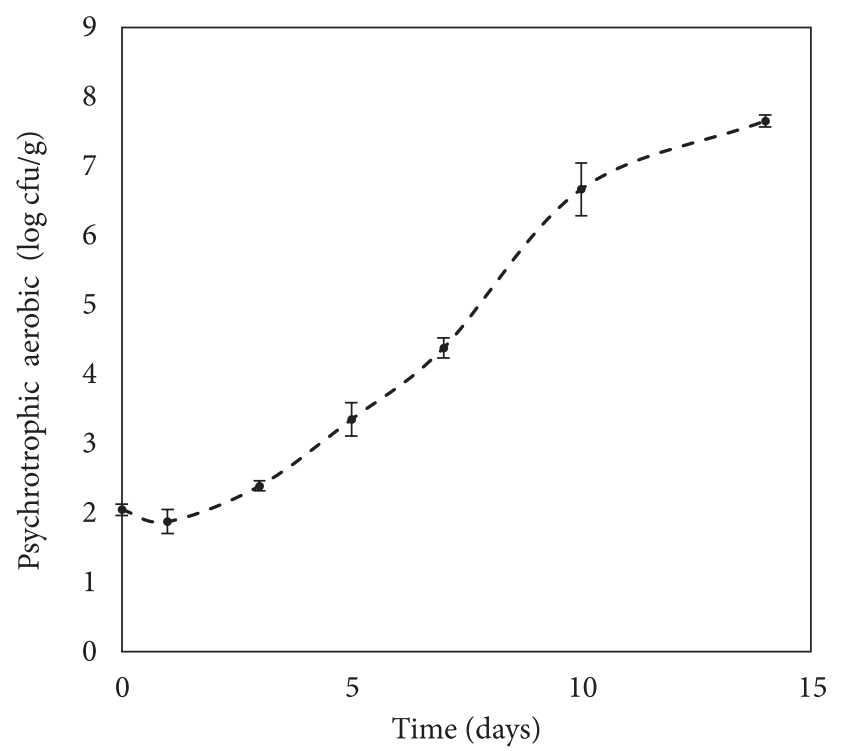

Figure 1. Psychrotrophic aerobic count in pork meat stored at $4{ }^{\circ} \mathrm{C}$ for 14 days. 
for bad odor (NYCHAS et al., 2008; PRANDL; FISCHER; SCHMIDHOFER, 1994).

Bomar (1985) suggests that a meat product may be considered acceptable for consumption when counting up to $6.7 \log \mathrm{cfu} / \mathrm{g}$, tolerable if it scores 6.7 to $7.7 \mathrm{log} \mathrm{cfu} / \mathrm{g}$, and unacceptable for consumption if it presents a count higher than $7.7 \log \mathrm{cfu} / \mathrm{g}$. From the results obtained in this study, the meat pork would be acceptable only before the $10^{\text {th }}$ day. Therefore, the $10^{\text {th }}$ day was considered the end point of shelf-life.

\section{$3.2 \mathrm{pH}$}

Tissue $\mathrm{pH}$ is widely used for monitoring of meat shelf-life (MANO; PEREDA; FERNANDO, 2002; MUELA et al., 2010; SWEETIE et al., 2010). The live muscle has $\mathrm{pH} 7.2$, while meat $\mathrm{pH}$ reaches values between 5.7 and 5.9 with post-mortem anaerobic glycolysis (SARCINELLI; VENTURINI; SILVA, 2007). With the complete deterioration, the meat $\mathrm{pH}$ can reach over 8.5 although an incipient degradation has already been found with values around pH 6.5 (JAY, 2000). As shown in Figure 2, the $\mathrm{pH}$ did not change substantially before the $10^{\text {th }}$ day; nevertheless, a sharp rising was observed after that time. This $\mathrm{pH}$ increase coincides with microbial counts higher than $10^{7} \mathrm{cfu} / \mathrm{g}$, as shown in Figure 1. Similar pattern was also reported by Mano, Pereda and Fernando (2002) for pork meat stored aerobically at 1 and $7{ }^{\circ} \mathrm{C}$. During storage, endogenous and microbial enzymes degrade meat proteins and produce ammonia and amines, which increase pH (JAY, 2000; GARCÍA-BARRIENTOS et al., 2006).

\subsection{Film performance}

The hue angle $\left(h_{a b}\right)$ and the chroma $\left(C^{*}\right)$ of the anthocyanin film are shown in Figures 3 and 4, respectively. Both $h_{a b}$ and $C^{*}$ undergone changes during storage. In the beginning, the anthocyanin films presented a more intense color. During storage, the films lost color intensity progressively and became achromatic ( $C^{\star}$ decrease), showing a more grayish color. This transition in chroma is clearly observed in Figure 3 although

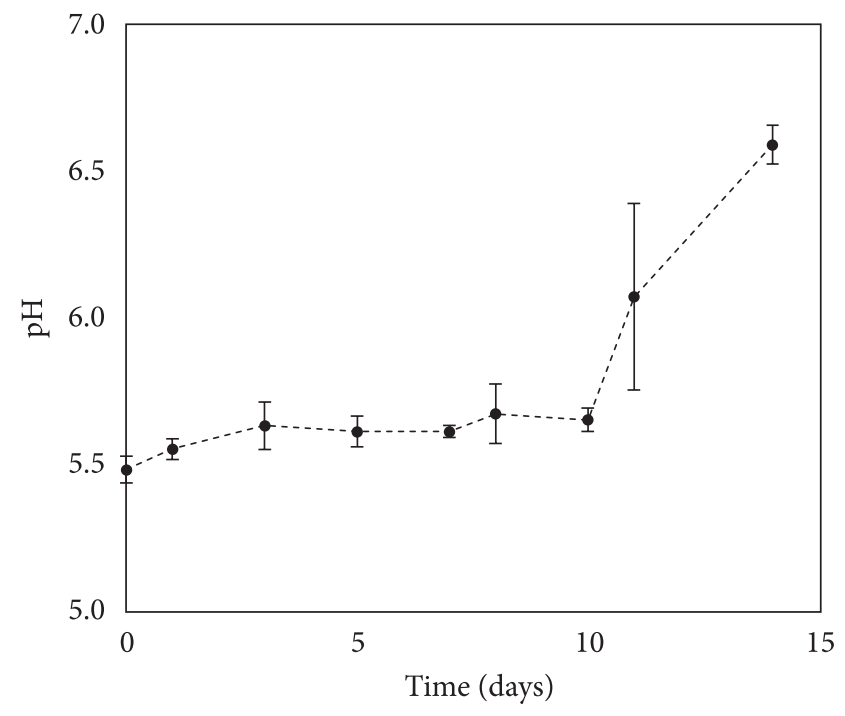

Figure 2. $\mathrm{pH}$ of pork meat stored at $4{ }^{\circ} \mathrm{C}$ for 14 days.

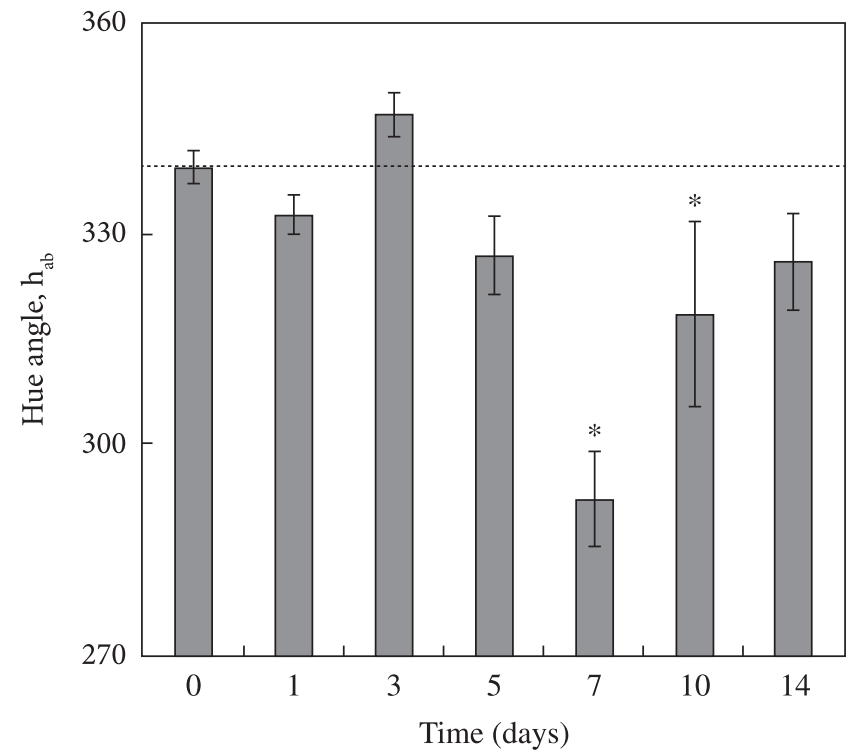

Figure 3. Hue angle of anthocyanins film in contact with pork meat stored at $4{ }^{\circ} \mathrm{C}$ for 14 days. Control group: anthocyanin films at zero time of storage, dashed line. Significant differences for the control group are indicated by ${ }^{\star}(\mathrm{P}<0.01)$ (Dunnett's test used after to ANOVA).

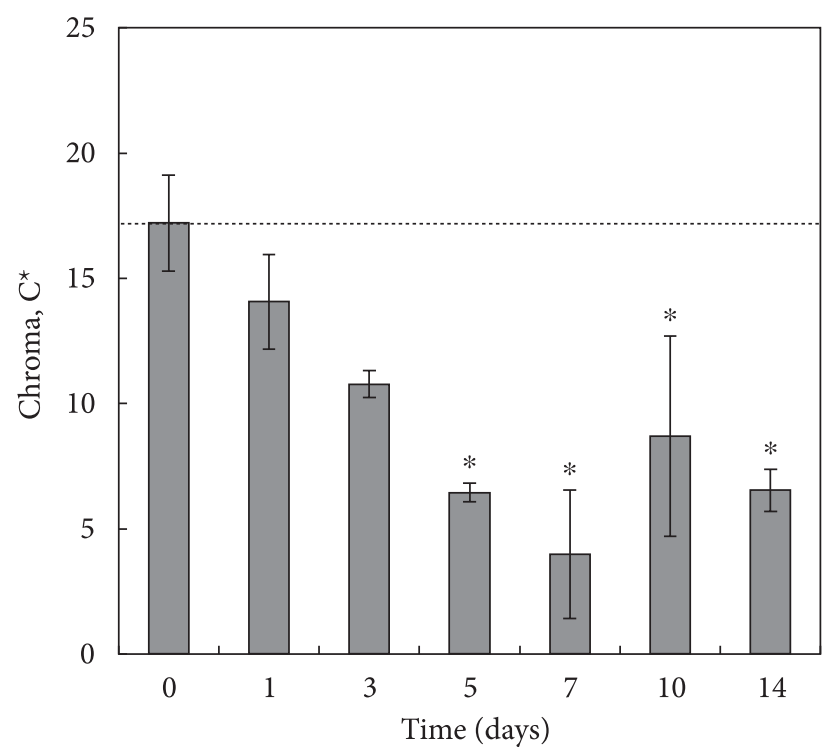

Figure 4. Chroma of anthocyanin films in contact with pork meat stored at $4{ }^{\circ} \mathrm{C}$ for 14 days. Control group: anthocyanin films at zero time of storage, dashed line. Significant differences for the control group are indicated by ${ }^{\star}(\mathrm{P}<0.01)$ (Dunnett's test used after ANOVA).

the decrease is only significant $(\mathrm{P}<0.01)$ from the $5^{\text {th }}$ day on. Between day zero and $7^{\text {th }}$ day, a significant $(\mathrm{P}<0.01)$ decrease in hue angle $\left(h_{a b}\right)$ was also observed, showing that the films changed from a reddish hue $\left(h_{a b}=339.53^{\circ}\right.$ at day zero) to a bluish hue $\left(h_{a b}=292.33^{\circ}\right.$ at $7^{\text {th }}$ day $)$.

The changes in the chroma and hue angle parameters may be due to the changes in the anthocyanin structure. According to Francis (1989), several factors can influence the color of the 
anthocyanins including their own chemical structure (number of hydroxyls, methylation degree and glycosylation), $\mathrm{pH}$, temperature, light, presence of oxygen, enzymatic degradation; and interactions with other substances such as sugars, metal ions, and copigments.

In acidic and neutral $\mathrm{pH}$ environments, four species of anthocyanins occur in equilibrium: quinoidal base, flavylium cation, carbinol pseudobase, and chalcone. Anthocyanins exhibit intense red color only in a very limited $\mathrm{pH}$ range (1.0 to 3.0), which represents an equilibrium between the red cation flavylium and the colorless carbinol base (LOPES et al., 2007; MARÇO; POPPI; SCARMINIO, 2008). As pH increases, kinetic and thermodynamic competition occurs between the hydration reaction of the flavylium cation and the proton transfer reactions related to the acidic hydroxyl groups of the flavylium cation. While the first reaction gives colorless carbinol pseudo-bases, which can undergo ring opening to yellow retro-chalcones, the last reactions give rise to more violet quinonoidal bases. Further deprotonation of the quinonoidal bases can take place at $\mathrm{pH}$ between 6 and 7 with the formation of more bluish resonance-stabilized quinonoid anions (TORSKANGERPOLL; ANDERSEN, 2005). The color intensity loss observed at about pH 6 may be due to the predominant forms with characteristics that do not accentuate the red color (LEE; DURST; WROLSTAD, 2005; MARÇO; POPPI; SCARMINIO, 2008).

Another hypothesis is that the depletion of glucose in pork loin by Pseudomonas led to instability of anthocyanin and induced changes in anthocyanin color, especially in chroma. From the $1^{\text {st }}$ to the $10^{\text {th }}$ day, there is a massive growth of spoilage microbiota (Figure 1), while the $\mathrm{pH}$ of meat remained almost unchanged (Figure 2). Although the microbial growth and spoilage products did not strongly affect the $\mathrm{pH}$ until $10^{\text {th }}$ day, they might have changed anthocyanin structure and influenced the color of the anthocyanin film.

Figure 5 shows the log-log plot of psychrotrophic counts $(\mathrm{cfu} / \mathrm{g})$ versus chroma in the beginning of storage time, from the $1^{\text {st }}$ to the $7^{\text {th }}$ day, when according to Dainty (1996), the incipient spoilage can be correlated directly with bacterial numbers. In the present study, that period of time practically coincides with the log phase of microbial growth, as shown in Figure 1. A satisfactory linear fitting of log-log plot $(\mathrm{R}=0.9990)$ in Figure 5 demonstrates the correlation between the film chroma and pork loin spoilage, and proves that the anthocyanin film was able to detected spoilage, at least up to the $7^{\text {th }}$ day. After that time, chroma did not show correlation with spoilage.

The effects of various monosaccharides and oligo- and polysaccharides on the stability and color of anthocyanins were also examinated by Lewis, Walker and Lancaster (1995), who demonstrated that the addition of glucose, maltose, and sucrose can result in an increase in anthocyanin absorbance. Similar results were obtained by Watanabe et al. (2011), who found that the addition of increasing amounts of sugars led to an increase in the strawberry jam chroma.

In the beginning of storage, glucose and lactic acid are the essential energy sources for the massive growth of microorganisms of the meat despite their negligible quantity

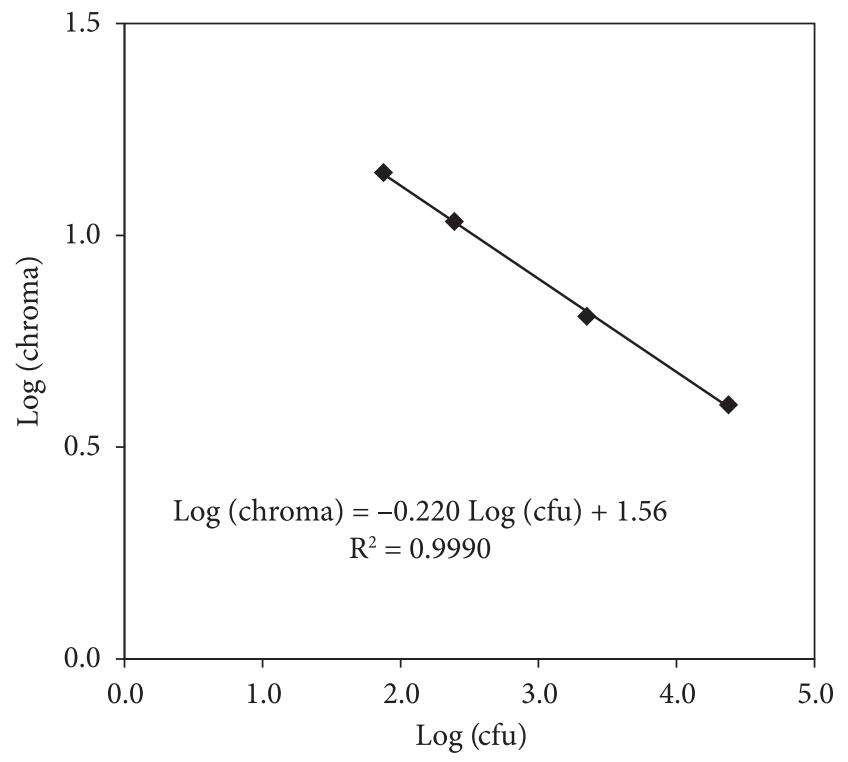

Figure 5. Log-log plot of psychrotrophic counts (cfu/g) versus chroma for the anthocyanin films in the beginning of storage time, from $1^{\text {st }}$ to $7^{\text {th }}$ day.

in comparison to proteins (NYCHAS et al., 2008). Depending on its initial concentration, glucose may become depleted and only at this point do other substrates begin to be metabolized including lactate, amino acids, and creatine under aerobic storage (DAINTY, 1996). According to the same author, the glucose gradient is correlated with bacterial numbers and can be related to incipient spoilage, thus providing a real evaluation of remaining shelf-life.

Although a correlation between film chroma and meat spoilage has been demonstrated up to the $7^{\text {th }}$ day, it is necessary to know whether consumers would be able to identify these differences. This issue is particularly important if a commercial application is pursued for this anthocyanin film. Veiga-Santos, Ditchfield and Tadini (2011) studied a novel biodegradable film with grape and spinach extracts (anthocyanin and chlorophyll) incorporated into a cassava starch matrix. The authors also reported a color change in CIELAB space when the films were exposed to different $\mathrm{pH}$ solutions; nevertheless, the color variation was only visible to the naked eye at extreme $\mathrm{pH}$ values.

The color difference $(\Delta \mathrm{E})$ is a useful attribute to evaluate the ability of the human eye to distinguish color differences (PIGATTO et al., 2011; SILVA; PETTER; SCHNEIDER, 2007) without using a sensory analysis panel. Figure 6 shows the color difference $(\Delta \mathrm{E})$ between the anthocyanin films during storage of pork loin and anthocyanin films at day zero, considered as the control. Pigatto et al. (2011) and Silva, Petter and Schneider (2007) used $\Delta \mathrm{E}$ as a quality parameter to evaluate the impact of processes on product color. These authors used the DIN $6174 / 1979$ as a reference to correlate $\Delta \mathrm{E}$ with the ability of the human eye to distinguish color difference. According to this standard, differences in color between two juxtaposed samples can be easily distinguishable for $\Delta \mathrm{E}$ bigger than 3.0 , while values above 6.0 represent a very large difference. Therefore, the 


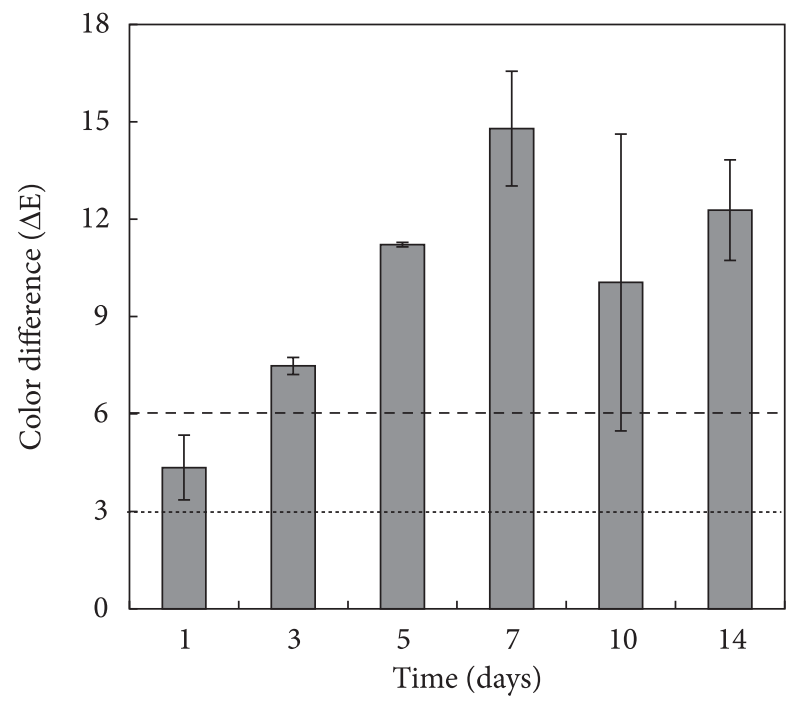

Figure 6. Color difference $(\Delta \mathrm{E})$ between the anthocyanin films during pork meat storage and anthocyanin films at time zero. Color difference easily distinguishable $(\Delta \mathrm{E}>3.0)$, dotted line; very large color difference $(\Delta \mathrm{E}>6.0)$, dashed line.

$\Delta \mathrm{E}$ values found in this study indicate that consumers would probably be able to distinguish changes in film color during storage if a color scale was shown in the product packaging. However, after the $7^{\text {th }}$ day, the $\Delta \mathrm{E}$ showed larger standard deviations leading to low reproducibility nearly to the point where the pork loin becomes unacceptable for consumption.

This study allowed us to assess the performance of a biobased film with anthocyanins as a deterioration indicator in a food system; a similar study has not yet been reported in the literature. Results obtained show that anthocyanin film changed its color during pork loin storage demonstrating correlation with bacteria number only on the first days of storage time. Nevertheless, anthocyanin film was not able to demonstrate clearly the end of shelf life, when the cfu values from the pork loin reach the accepted limit for consumption, more detailed studies will be necessary in order to try using anthocyanin films as indicators of pork spoilage. Further studies should include the use other sources of anthocyanin and a complete film characterization in order to better understand the changes undergone by the anthocyanins structure in response to color changes in the film. In addition, it would be interesting to consider the use of a control film during storage in order to observe the influence of other factors such as light and temperature on the color of anthocyanin.

\section{Conclusion}

The developed bio-based film with anthocyanin was able to detect changes in the chilled pork during storage through changes in the film color, with differences that could be detected by the human eye. However, only at the beginning of the storage period, was it possible to establish a correlation between the color of the film and the number of spoilage microorganisms, when spoilage was still incipient. The end point of the shelf life could not be clearly determined. Therefore, further studies must be conducted using a film with anthocyanin as an indicator of deterioration chilled pork.

\section{Acknowledgements}

The authors are grateful for the financial support provided by the University of Vale do Rio dos Sinos (UNISINOS).

\section{References}

AHVENAINEN, R. Active and intelligent packaging: an introduction. In: AHVENAINEN, R. Novel food packaging technique. Boca Raton: CRC Press, 2003. p. 5-21. http://dx.doi. org/10.1533/9781855737020.1.5

ALIBERT, N. C. M. Influência da homogeneização a alta pressão sobre a retenção de antocianinas presentes na polpa de açaí (Euterpe oleraceae Mart.). 2009. 98 f. Tese (Doutorado em Engenharia Química)-Escola Politécnica, Universidade de São Paulo, São Paulo, 2009.

AMERICAN PUBLIC HEALTH ASSOCIATION - APHA. Compedium of methods for the microbiolgial exanination of foods. 4th ed. Washington: APHA, 2001.676 p.

BOMAR, M. T. Rapid method for the determination of bacterial surface contamination in carcasses. Alimenta, v. 24, n. 3, p. 55-57, 1985.

BORDIGNON JUNIOR, C. L. et al. Influência do pH da solução extrativa no teor de antocianinas em frutas de morango. Ciência e Tecnologia de Alimentos, v. 29, n. 1, p. 183-188, 2009. http:// dx.doi.org/10.1590/S0101-20612009000100028

BOTREL, D. A. et al. Qualidade de alho (Allium sativum) minimamente processado envolvido com revestimento comestível antimicrobiano. Ciência e Tecnologia de Alimentos, v. 27, n. 1, p. 32-38, 2007. http:// dx.doi.org/10.1590/S0101-20612007000100006

DAINELLI, D. et al. Active and intelligent food packaging: legal aspects and safety concerns. Trends in Food Science \& Technology, v. 19, p. S103-S112, 2008. http://dx.doi.org/10.1016/j.tifs.2008.09.011

DAINTY, R. H. Chemical/biochemical detection of spoilage. International Journal of Food Microbiology, v. 33, p. 33, 1996. http://dx.doi.org/10.1016/0168-1605(96)01137-3

FAVARO, M. M. A. Extração, estabilidade e quantificação de antocianinas de frutas típicas brasileiras para aplicação industrial como corantes. 2008. 105 f. Dissertação (Mestrado em Química)-Instituto de Química, Universidade Estadual de Campinas, Campinas, 2008.

FRANCIS, F. J. Food colorants: anthocyanins. Critical Review of Food Science and Nutrition, v. 28, n. 4, p. 273-314, 1989. http://dx.doi. org/10.1080/10408398909527503

GARCÍA-BARRIENTOS, R. et al. Changes in pork and shark (Rhizopriondon terraenovae) protein emulsions due to exogenous and endogenous proteolytic activity. Food Research International, v. 39, n. 9, p. 1012-1022, 2006. http://dx.doi.org/10.1016/j. foodres.2006.07.004

GONNET, J. F. Colour effects of co-pigmentation of anthocyanins revisited: 1. a colorimetric definition using the CIELab scale. Food Chemistry, v. 63, n. 3, p. 409-415, 1998. http://dx.doi.org/10.1016/ S0308-8146(98)00053-3

GOUVÊA, A. C. M. S. et al. Anthocyanins standards (cyanidin-3-Oglucoside and cyanidin-3-O-rutinoside) isolation from freeze-dried açaí (Euterpe oleraceae Mart.) by HPLC. Ciência e Tecnologia de Alimentos, v. 32, n. 1, p. 43-46, 2012. http://dx.doi.org/10.1590/ S0101-20612012005000001 
HAN, J. H.; HO, C. H. L.; RODRIGUES E. T. Intelligent packaging. In: HAN, J. H. (Ed.). Innovations in food packaging. Baltimore: Elsevier Science \& Technology Books, 2005. cap. 9, p. 138-155.

HORAN, T. J. Method for determining bacterial contamination in food package. US n. 5753285, May 191998.

INTERNATIONAL COMISSON ON MICROBIOLOGICAL SPECIFICATIONS FOR FOODS - ICMSF. Ecologia microbiana de los alimentos: productos alimentícios. Zaragoza: Acribia, 1980. v. 2, $332 \mathrm{p}$.

JAY, J. M. Modern food microbiology. 6th ed. Gaithersburg: Aspen Publishers, 2000. 635 p. http://dx.doi.org/10.1007/978-1-46154427-2

KERRY, J. P.; O'GRADY, M. N.; HOGAN, S. A. Past, current and potential utilization of active and intelligent packaging systems for meat and muscle-based products: a review. Meat Science, v. 1, n. 74, p. 113-130, 2006. http://dx.doi.org/10.1016/j.meatsci.2006.04.024

KRUIJF, N. et al. Active and intelligent packaging: applications and regulatory aspects. Food Additives and Contaminants, v. 19, p. 144-162, 2002. Supplement. http://dx.doi.org/10.1007/s11694011-9120-X

KUSWANDI, B. et al. Smart packaging: sensors for monitoring of food quality and safety. Sensing and Instrumentation for Food Quality and Safety, v. 5, p. 137-146, 2011. http://dx.doi.org/10.1007/ s11694-011-9120-x

LEE, J.; DURST, R. W.; WROLSTAD, R. E. Determination of total monomeric anthocyaninin pigment content of fruit juices, beverages, natural colorants, and wines by the $\mathrm{pH}$ differential method: collaborative study. Journal of AOAC International, v. 88, n. 5, p. 1269-1278, 2005.

LEWIS, C. E.; ALKER, J. R. R.; LANCASTER, J. E. Effect of polysaccharides on the colour of anthocyanins. Food Chemistry, v. 54, p. 315-3, 1995. http://dx.doi.org/10.1016/03088146(95)00026-F

LIMA, A. J. B. et al. Anthocyanins, pigment stability and antioxidant activity in jabuticaba. Revista Brasileira de Fruticultura, v. 33, n. 3, p. 877-887, 2011. http://dx.doi.org/10.1590/S010029452011000300023

LOPES, T. et al. Antocianinas: Uma breve revisão das características estruturais e da estabilidade. Revista Brasileira de Agrociência, v. 13, n. 3, p. 291-297, 2007.

MACIEL, V. B. V.; YOSHIDA, C. M. P.; FRANCO, T. T. Development of a prototype of a colourimetric temperature indicator for monitoring food quality. Journal of Food Engineering, v. 111, n. 1, p. 21-27, 2012. http://dx.doi.org/10.1016/j.jfoodeng.2012.01.037

MANO, S. B.; PEREDA, J. A. O.; FERNANDO, G. D. G. Aumento da vida útil e microbiologia da carne suína embalada em atmosfera modificada. Ciência e Tecnologia de Alimentos, v. 22, n. 1, p. 1-10, 2002. http://dx.doi.org/10.1590/S0101-20612002000100002

MARÇO, P. H.; POPPI, R. J.; SCARMINIO, I. S. Procedimentos analíticos para identificação de antocianinas presentes em extratos naturais. Química Nova, v. 31, n. 5, p. 1218-1223, 2008. http:// dx.doi.org/10.1590/S0100-40422008000500051

MATTILA, T.; TAWAST, J.; AHVENAINEN, R. New possibilities for quality control of aseptic packages: microbiological spoilage and seal defect detection using headspace indicators. LebensmittelWissenschaft und -Technologie, v. 23, n. 3, p. 246-251, 1990.

MAZZA, G.; BROUILLARD, R. The mechanism of co-pigmentation of anthocyanins in aqueous solutions. Phytochemistry, v. 29, n. 4, p. 1097-1102, 1990. http://dx.doi.org/10.1016/0031-9422(90)854118
MUELA, E. et al. Effect of freezing method and frozen storage duration on instrumental quality of lamb throughout display. Meat Science, v. 84, n. 4, p. 662-669, 2010. http://dx.doi.org/10.1016/j. meatsci.2009.10.028

NYCHAS, G.-J. E. et al. Meat spoilage during distribution. Meat Science, v. 78, n. 1-2, p. 77-89, 2008. PMid:22062098. http://dx.doi. org/10.1016/j.meatsci.2007.06.020

NOPWINYUWONG, A.; TREVANICH, S.; SUPPAKUL, P. Development of a novel colorimetric indicator label for monitoring freshness of intermediate-moisture dessert spoilage. Talanta, v. 81, p. 1126-1132, 2010. http://dx.doi.org/10.1016/j.talanta.2010.02.008

PACQUIT, A. et al. Development of a volatile amine sensor for the monitoring of fish spoilage. Talanta, v. 69, n. 2, p. 515-520, 2006. http://dx.doi.org/10.1016/j.talanta.2005.10.046

PACQUIT, A. et al. Development of a smart packaging for monitoring of fish spoilage. Journal of Food Chemistry, v. 102, n. 2, p. 466-470, 2007. http://dx.doi.org/10.1016/j.foodchem.2006.05.052

PAVELKOVÁ, A. Intelligent packaging as device for monitoring of risk factors in food. Journal of Microbiology, Biotechnology and Food Sciences, v. 2, n. 1, p. 282-292, 2012.

PIGATTO, P. et al. Impacto do processo de secagem na cor das folhas da Mentha piperita. In: SIMPÓSIO DE INOVAÇÃO TECNOLÓGICA, 3., Cascavel, 2011. Anais... Cascavel: Unioeste, 2011.

PULIGUNDLA, P.; JUNG, J.; KO, S. Carbon dioxide sensors for intelligent food packaging applications. Food Control, v. 25, p. 328-333, 2012. http://dx.doi.org/10.1016/j.foodcont.2011.10.043

PRANDL, O.; FISCHER, A.; SCHMIDHOFER, T. Tecnología e higiene de la carne. Zaragoza: Acribia, 1994. 854 p.

RANDELL, K. et al. Modified atmosphere-packed marinated chicken breast and rainbow trout quality as affected by package leakage. Journal of Food Science, v. 60, n. 4, p. 667-684, 1995. http://dx.doi. org/10.1111/j.1365-2621.1995.tb06203.x

REALINI, C. E. et al. Hight pressure and freezing temperature effect on quality and microbial inactivation of cured pork carpaccio. Meat Science, v. 88, n. 3, p. 542-547, 2011. http://dx.doi.org/10.1016/j. meatsci.2011.02.008

RESTUCCIA, D. et al. New EU regulation aspects and global market of active and intelligent packaging for food industry applications. Food Control, v. 21, n. 11, p. 1425-1435, 2010. http://dx.doi.org/10.1016/j. foodcont.2010.04.028

ROBERTSON, G. L. Food packaging: principles and practice. New York: Marcel Dekker, 1993. 686 p.

SARCINELLI, M. F.; VENTURINI, K. S.; SILVA, L. C. Características da carne suína. Vitória: UFES, 2007. 7 p. (Boletim Técnico, PIEUFES:00907).

SCHANDA, J. (Ed.). Colorimetry: understanding the CIE system. Hoboken: John Wiley e Sons, 2007. 459 p.

SILVA, R. A.; PETTER, C. O.; SCHNEIDER, I. A. H. Avaliação da perda da coloração artificial de agatas. Revista Escola de Minas, v. 60, n. 3, p. 477-482, 2007. http://dx.doi.org/10.1590/S037044672007000300007

SILVA, J. et al. Cassava's starch biostrip as food $\mathrm{pH}$ indicator. In: FRENCH BRAZILIAN MEETING ON POLYMERS, 3., Florianópolis, 2011. Anais... Florianópolis, 2011. p. A49.

SMOLANDER, M. et al. Myoglobin-based indicators for the evaluation of freshness of unmarinated broiler cuts. Innovative Food Science and Emerging Technologies, v. 3, n. 3, p. 277-85, 2002. http:// dx.doi.org/10.1016/S1466-8564(02)00043-7 
SIRACUSA, V. et al. 2010. Biodegradable polymers for foodpackaging - a review. Trends in Food Science \& Technology, v. 19, n. 12, p. 634-643, 2008.

SOARES, N. F. F. Novos desenvolvimentos e aplicações em embalagens de alimentos. Ceres, v. 56, n. 4, p. 370-378, 2009.

STRACK, D.; WRAY, V. The anthocyanins. In: HARBORNE, J. B. (Ed.). The Flavonoids: advances in research since 1986. New York: Chapman \& Hall/CRC, 1994. p. 1-22.

SWEETIE, R. K. et al. Shelf-life extension of convenience meat products sold in Indian supermarkets by radiation processing. Radiation Physics and Chemistry, v. 79, n. 12, p. 1259-1263, 2010. http:// dx.doi.org/10.1016/j.radphyschem.2010.07.008

TORSKANGERPOLL, K. ANDERSEN, O. M. Colour stability of anthocyanins in aqueous solutions at various $\mathrm{pH}$ values. Food
Chemistry, v. 89, n. 3, p. 427-440, 2005. http://dx.doi.org/10.1016/j. foodchem.2004.03.002

VEIGA-SANTOS, P.; DITCHFIELD, C.; TADINI, C. C. Development and evaluation of a novel $\mathrm{pH}$ indicator biodegradable film based on cassava starch. Journal of Applied Polymer Science, v. 120, p. 1069-1079, 2011. http://dx.doi.org/10.1002/app.33255

WATANABE, Y. Effect of impregnation using sucrose solution on stability of anthocyanin in strawberry jam. Food Science and Technology, n. 44, p. 891-895, 2011.

YAM, K. L.; TAKHISTOV, P. T.; MILTZ, J. Intelligent packaging: concepts and applications. Journal of Food Science, v. 70, n. 1, p. R1-R10, 2005. http://dx.doi.org/10.1111/j.1365-2621.2005. tb09052.x 